\title{
Litter Breakdown among Intermittently Connected and Unconnected Geographically Isolated Wetlands (GIWs): How Nutrient Pulses Alter Wetland Function
}

Chelsea R. Smith ( $\nabla$ chelsea.smith@jonesctr.org )

The Jones Center at Ichauway https://orcid.org/0000-0002-7601-8739

Stephen W. Golladay

The Jones Center at Ichauway

Carla L. Atkinson

The University of Alabama

Brian A. Clayton

The Jones Center at Ichauway

Research Article

Keywords: macroinvertebrates, land use, agriculture, nutrient subsidies, decomposition

Posted Date: November 4th, 2021

DOI: https://doi.org/10.21203/rs.3.rs-941298/v1

License: (1) This work is licensed under a Creative Commons Attribution 4.0 International License. Read Full License 


\section{Abstract}

Geographically isolated wetlands (GIWs) comprise a significant portion of the wetlands in the U.S., connecting to surrounding landscapes in varying ways and providing diverse ecosystem functions. Understanding the consequences of wetland connections across space and time are crucial in understanding GIW function. We compared nutrient concentrations, litter breakdown, and associated macroinvertebrate communities from 2018-2019 in three wetlands connected by an intermittent flow path to agricultural fields, to three unconnected GIWs. Litter bags were constructed of two mesh sizes to reduce macroinvertebrate abundances. We observed increased breakdown with increased connection to agricultural fields, likely the result of increased nutrients such as phosphorus increasing microbial activity. Enhanced breakdown in the connected wetlands was transient, varying between years with the degree of connection. While water quality measures did not consistently show increased nutrient levels across all connected wetlands, lower litter N:P within connected wetlands provided a broader look at nutrient subsidies. Macroinvertebrate abundance was greater in connected wetlands when connection occurred and shredder abundance was greater later during breakdown, however high variability obscured any pattern with breakdown rates. Comparing litter decomposition rates in our study to previous studies, we note that our connected wetlands functioned more similarly to flowing waters while the unconnected wetlands functioned similar to discrete wetlands. Future climate predictions indicate increased winter rainfall for this region which will increase the degree and frequency of hydrologic connection and associated nutrient transport. Understanding how seasonal variability alters wetland function is important in understanding the roles wetlands play in landscape ecosystem function.

\section{Intro}

Geographically isolated wetlands (GIWs) are a significant portion of the wetlands in the U.S. and include prairie potholes, vernal pools, playas, Carolina Bays, and cypress domes (Tiner 2003). While GIWs are surrounded by uplands, they are often hydrologically, biologically and biogeochemically connected to the surrounding landscape, playing critical roles in sediment deposition, nutrient retention and transformation, as well as supplying critical habitat for many taxa (Craft and Casey 2000; Capps et al. 2014; Cohen et al. 2016). Landscapes often contain a patchwork of different land-uses that can connect to wetlands in varying degrees. To fully understand their role within the landscape, knowledge of how connectivity influences wetland ecosystem function is needed.

Due to lack of perennial connection to 'Waters of the US' (WOTUS) and intermittent hydrology, GIWs mostly lack federal protection, leaving them vulnerable to alteration at many scales (Zedler 2003; Cohen et al. 2016). Previous studies have compared wetlands in undisturbed areas to those embedded in agricultural or urban settings (Faulkner 2004; Atkinson et al. 2011; Botello et al. 2013); however few studies have examined the indirect effects of broader surrounding land-use (but see, Fuell et al. 2013; Deemy and Rasmussen 2017). During wet periods, low topography within regions such as the Coastal Plain allows for connection (i.e., intermittent water flow) to occur among some wetlands, across adjacent uplands, and even connecting these typically isolated waterbodies to perennial surface waters. GIWs 
embedded in agricultural settings have been shown to have increased levels of nitrate, soluble reactive phosphorous, carbon and suspended sediments compared to reference sites because of runoff from adjacent fields (Reiss 2006; Atkinson et al. 2011; Botello et al. 2013). Periods of hydrologic connection can result in pulses of nutrients as well as movement of organisms such as fish that would normally be excluded from wetlands due to seasonal drying. This influx of nutrients and organisms has the potential to greatly alter ecosystem function within GIWs depending on their degree of isolation and adjacent land use.

Understanding the significance of intermittent connectivity can be enhanced by examining wetland functional attributes in addition to changes in biota or water quality. GIWs have been identified as biogeochemical "hot spots" for their role in litter decomposition, denitrification, and other processes relative to the surrounding landscape (McClain et al. 2003; Capps et al. 2014). Litter breakdown is commonly used a metric for ecosystem function across wetlands and streams (Richardson 1994; Gessner and Chauvet 2002; Tank et al. 2010) Multiple studies have shown that increases in nutrient availability can accelerate litter breakdown (Rosemond et al. 2010; Taylor et al. 2017). In addition, nutrient-rich sediments in contact with litter can also increase breakdown rate (Fortino et al. 2020). Aside from direct inputs of nutrients, changes in biota will also influence breakdown rates within GIWs. The addition of fish typically enhances nutrient subsidies and leads to altered macroinvertebrate and amphibian communities normally accustomed to fishless environments (Pechmann et al. 1989; Kohler et al. 1999). Finally, as wetlands dry, additional nutrients will remain as carrion following mortality and desiccation (Paramenter and Lamarra 1991; Vanni 2002). Collectively, these abiotic and biotic attributes influence leaf litter decomposition which is an important ecosystem functional metric that integrates the overall effect of intermittent connectivity.

The purpose of our study was to examine how intermittent connectivity during wet periods affects GIW litter breakdown in wetlands embedded in a mature second-growth longleaf pine forest. Over a two-year period, we compared three wetlands connected to distant agricultural fields along an intermittent flow path to those that are unconnected. We hypothesized that litter breakdown rates would be greater in wetlands periodically connected to agricultural lands compared to unconnected wetlands largely because of increased nutrient availability. In addition, we tested whether invertebrate abundances differed between these wetland types and whether this change would affect breakdown rates by comparing litter bags of two different mesh sizes. We expected coarse mesh bags to have a faster breakdown rate because of greater invertebrate activity, with this difference reduced in connected wetlands as a result of reduced abundances of detritivore invertebrates with the presence of larger fish predators.

\section{Methods}

\section{Study Area}

Leaf breakdown studies were conducted in cypress-gum swamp GIWs located at The Jones Center at Ichauway in Baker County, Georgia. Ichauway is an 11,400 ha property dominated by mature second- 
growth, fire-maintained longleaf pine. Ichauway lies within the Dougherty plain, a karst landscape with 10,000 GIWs, and contains $~ 100$ wetlands within its boundaries (Martin et al. 2012). Mean annual rainfall for the region is $1310 \mathrm{~mm}$ with a mean annual temperature of $19.7^{\circ} \mathrm{C}$ ranging between $-7.4^{\circ}$ and $39^{\circ} \mathrm{C}$ (georgiaweather.net). The landscape surrounding Ichauway has substantial irrigated agriculture, largely corn, cotton and peanuts (Fig. 1a). Three of our study wetlands have no connection (i.e., 'unconnected') to other wetlands or areas via overland flow while the other three (i.e., 'connected') fall along an intermittent flow path connecting them to each other as well as agriculture fields outside of Ichauway (Fig. 1a). The connection generally occurs when heavy rainfall initiates runoff from upstream agricultural fields that then "fills and spills" through each of the three connected weltands. Wetlands are dominated by swamp black gum (Nyssa sylvatica var. biflora (Walt) Sarg.) and pond cypress (Taxodium ascendens (Brongn.)) (Watt and Golladay 1999).

\section{Water Quality}

At the time of each litter bag retrieval, $1 \mathrm{~L}$ water samples were collected at each sampling location. If the litter bag location was dry, a sample was taken from the nearest pooled water within the wetland except for the 27th of June, 2018 when only small pools remained in two of the six wetlands. Bottles were placed on ice and returned to the lab to be filtered (Whatman GFF, 0.7- $\mu \mathrm{m}$ pore size) and separated into aliquots for subsequent analysis. Dissolved carbon (total, inorganic, and organic) subsamples were stored at $4^{\circ} \mathrm{C}$ and analyzed within a month of sampling using Shimadzu TOC-L. $\mathrm{NH}_{4}-\mathrm{N}$ subsamples were preserved with sulfuric acid, stored at $4^{\circ} \mathrm{C}$ and analyzed within one month. $\mathrm{NO}_{3}-\mathrm{N}$, soluble reactive phosphorus (SRP), total dissolved nitrogen (TDN) and phosphorus (TDP) were frozen and analyzed within six months. TDN and TDP were digested using a persulfate method. $\mathrm{NH}_{4}-\mathrm{N}, \mathrm{NO}_{3}-\mathrm{N}, \mathrm{SRP}, \mathrm{TDN}$ and TDP were determined with a Lachat Quickchem 8000 flow-injection using colorimetric methods (Lachat Instruments 1998). Depth and temperature at the deepest location were recorded in each wetland in hourly intervals using HOBO data loggers (Onset Computer Corporation, Pocasset, MA, USA). Depth at each litter location was also recorded at each sampling event.

\section{Litter Decomposition, stoichiometry and macroinvertebrates}

We used Swamp Black Gum leaves in mesh litter bags to measure litter decomposition. We constructed $30 \times 16 \mathrm{~cm}$ bags of both 5-mm plastic mesh pecan bags (coarse mesh) to allow shredders access and $0.5 \mathrm{~mm}$ mesh bags (fine mesh) to exclude shredders. Senescent leaves were collected in unconnected wetlands using suspended nets in October 2017 and September 2018 and allowed to air dry for at least $48 \mathrm{~h}$ at room temperature. Approximately $5 \mathrm{~g}$ of dried litter was weighed to the nearest $0.01 \mathrm{~g}$ and placed within each mesh bag. The litter bags were anchored at three sites within each wetland in December 2017 and two sites within each wetland in January 2019. All wetlands were dry when litter was placed in December of 2017 and sampling began upon their filling on February 13th, 2018. Because wetlands never completely dried in the fall of 2018 and to maintain comparable temperatures, litter bags were placed in already inundated wetlands on January 9th 2019. Each initial deployment was designated day 0 for 
collections in each year. A total of 360 litter bags were deployed in 2018 (6 wetlands $x 3$ sites/wetland $\times 2$ mesh sizes $\times 10$ sampling dates) and 240 in 2019 with only 2 sites/wetland ( 6 wetlands $\times 2$ sites/wetland $x 2$ mesh sizes $x 10$ sampling dates).

Litter samples were collected on day $0,1,8,15,22,50,78,106,134$, and 162 in 2018, and 0, 1, 7, 14, 21, 49, 77, 105, 139 and 162 in 2019 (Fig. 1b,c). In the laboratory following collection, leaves were removed from their bags and rinsed over a $250 \mu \mathrm{m}$ sieve to remove macroinvertebrates and loose sediment.

Leaves were then dried at $70^{\circ} \mathrm{C}$ until mass stabilized before being weighed to the nearest $0.01 \mathrm{~g}$ and ground for subsampling (Spex $8000 \mathrm{D}$ ball grinder). Subsamples of $0.5 \mathrm{~g}$ were ashed for $4 \mathrm{~h}$ at $500^{\circ} \mathrm{C}$ to determine ash-free dry mass (AFDM). Samples were analyzed for \%C and \%N using a 'Flash 2000' organic elemental analyzer (C.E. Elantech, Lakewood, New Jersey, USA). Phosphorus was determined by weighing samples, combusting at $500^{\circ} \mathrm{C}$ for $2 \mathrm{~h}$, and then digesting with $1 \mathrm{~N} \mathrm{HCL}$ followed by SRP analysis on a UV Spectrophotometer (Solórzano and Sharp 1980). Macroinvertebrates were separated from the leaf litter, preserved in ethanol and on selected days (below) identified to the lowest possible taxonomic level, generally genus for insects except for Chironomidae (Non-tanypodinae, Tanypodinae) (Merritt et al. 2008; Thorp and Covich 2009). Samples collected on days 1, 8 (2018) or 7 (2019), and 50 (2018) or 77 (2019) were identified to quantify any possible initial conditions as well as a likely maximum colonization point for invertebrates (Fig. 1C) (Fuell et al. 2013). An earlier time point for maximum colonization was selected in 2018 as wetlands began to dry after this point.

\section{Data Analysis}

To examine how connection to the surrounding landscape effects water quality (i.e., DOC, $\mathrm{NH}_{4}-\mathrm{N} \mathrm{NO}_{3}-\mathrm{N}$, SRP, TDN, TDP), log transformed measures were compared using mixed models examining the interaction between wetland type (connected and unconnected) and date sampled as a factor with wetland as random effect to account for repeated measures.

Breakdown rates $(k)$ were calculated by plotting the natural $\log (-\ln )$ of percent AFDM remaining vs days in the wetland $\left(\mathrm{d}^{-1}\right)$ (Benfield 2006). Leaf breakdown rates were estimated using the negative exponential decay model, $M_{t} / M_{0}=e^{-k t}$ where $M_{t}$ is the leaf mass remaining at time $t$ and $M_{0}$ is the initial leaf mass. To evaluate the effect of wetland type (connected versus unconnected), mesh size (coarse versus fine) and year (2018 versus 2019), we conducted a three-factor mixed effect model. We included the location within each wetland as a random effect to account for non-independence at each litter bag deployment. Model selection was performed using AIC to obtain the most parsimonious model followed by post hoc comparisons. Change in litter nutrient percentages $(N, P, C)$ from initial sampling were graphed and compared qualitatively. Final C: N, C: P and N: P ratios were compared (Day 162) using a mixed model examining wetland type, mesh size and year with a random effect of wetland litter deployment location, and post hoc comparisons were performed similarly as breakdown rates.

Total invertebrate abundance and shredder abundance were log +1 transformed and compared with mixed models across three sampling points to assess colonization across wetland type, mesh size and year. All analyses were performed in R 4.0.3 using 'Ime4'; comparisons were made using the 'emmeans' 
package and plots were made using 'ggplot2' (Bates et al. 2015; Wickham 2016; Lenth 2020).

Significance was designated as $p \leq 0.05$ and marginally significant at $0.05<p \leq 0.10$.

\section{Results}

\section{Physiochemical Properties}

Wetland conditions differed between years with 2018 having a relatively short hydroperiod ( 120 days) compared to 2019 ( 365 days). While rainfall totals were similar between water years 2018 and 2019, at 1259 and $1420 \mathrm{~mm}$ respectively, the timing was different (Fig. 1b). Litter bags inundated in February of 2018 and most wetlands were dry at the deepest location by late June, though our litter sites tended to dry in late April to early May 2018. Because many of our litter sites within wetlands never inundated during 2018, a subset that did inundate were chosen for analysis between wetland types (5 locations across 3 wetlands of each type). Heavy rains in mid-July 2018 refilled the wetlands and they maintained water levels through the following water year. Intermittent flow from agriculture fields was established for a short period at the start of 2018 sampling but only connected to W69, the most upstream wetland along the path. Because of generally wetter conditions in 2019, flow connected to all wetlands from the start of sampling through early April and all litter sites were inundated for the sampling period.

Water quality patterns differed between years with generally greater concentrations seen across all parameters upon initial filling in 2018 as compared to increasing values over the sampling period in 2019. We found that dissolved organic carbon (DOC) varied by sampling date $\left(F_{16,149}=33.44, p<0.001\right)$ and due to the interaction of wetland type and date $\left(F_{16,149}=2.95, p<0.001\right)$, but not between wetland types $\left(F_{1,149}=2.16, p=0.216\right)$. Post hoc comparisons revealed that $D O C$ levels were similar between wetland types in 2018 and at the start of sampling in 2019 but diverged in late April and marginally in late May with greater levels in unconnected wetlands before becoming similar on the final sampling date (Fig. 2a). TDN varied significantly across sampling date $\left(F_{16,149}=12.46, p<0.001\right)$ and the interaction of wetland type and sampling date $\left(F_{16,149}=346, p<0.001\right)$, but not due to wetland type alone $\left(F_{1,149}=1.97, p\right.$ $=0.233$ ). Upon filling, unconnected wetlands had a TDN pulse resulting in greater initial values, followed by similar levels between wetland types for the remainder of the sampling year. In 2019, unconnected wetlands tended to have greater TDN values, but a significant difference was only detected in late April (Fig. $2 b)$. TDP only varied by sampling date $\left(F_{16,149}=8.43, p<0.001\right)$. Though no significance was detected, TDP levels in the connected wetlands declined from the most upstream wetland downstream (Fig. 2C). Dissolved inorganic carbon (DIC) varied by wetland type $\left(F_{1,149}=32.21, p=0.004\right)$, date sampled $\left(F_{16,149}=15.63, p<0.001\right)$ and their interaction $\left(F_{16,149}=6.05, p<0.001\right)$. DIC values were similar upon initial filling in 2018 followed by a significant increase in connected wetlands that remained for the sampling year. In 2019, levels generally remained similar in the first month of sampling followed by a significant increase in connected wetlands for the remainder of the year. $\mathrm{NH}_{4}-\mathrm{N}$ varied across date sampled $\left(F_{16,149}=16.05, p<0.001\right)$ and marginally due to the interaction $\left(F_{16,149}=1.65, p=0.064\right)$, but not across wetland type $\left(\mathrm{F}_{1,149}=0.19, \mathrm{p}=0.691\right)$. We saw similar trends with $\mathrm{NO}_{3}-\mathrm{N}$ with concentrations 
varying across date $\left(\mathrm{F}_{16,149}=19.20, \mathrm{p}<0.001\right)$, but not across wetland type or their interaction $\left(F_{16,149}=0.70,1.57, p=0.448,0.084\right)$. In 2018 , an initial $\mathrm{NO}_{3}-\mathrm{N}$ pulse occurred in unconnected wetlands upon filling followed by similar levels between wetland types for the remainder of sampling. In $2019, \mathrm{NO}_{3}{ }^{-}$ $\mathrm{N}$ levels began low and tended to increase over time. Sampling date $\left(F_{16,149}=3.03, p<0.001\right)$ and the interaction of wetland type and date were significant for $\operatorname{SRP}\left(F_{16,149}=2.53, p=0.002\right)$. SRP concentrations in connected wetlands were significantly greater than unconnected wetlands on the first sampling date and again in late May just before most sites dried in 2018. This difference was largely due to high SRP levels detected in the most upstream wetland, W69. In 2019, while connected wetlands tended to have greater SRP values, there was no significant difference (Supplement Table 1).

\section{Leaf-Litter Decomposition and Nutrient Composition}

Leaf litter decomposition did not vary as a result of litter bag mesh size $\left(F_{1,39}=1.74, p=0.200\right)$ or wetland type $\left(F_{1,39}=1.9, p=0.195\right)$. However, litter decomposition varied by year $\left(F_{1,39}=37.20, p<0.001\right)$ and the interaction of wetland type and year $\left(F_{1,39}=17.47, p<0.001\right)$. In 2018 , no significant difference in breakdown rates were observed between wetland types, while in 2019, connected wetlands had significantly faster breakdown rates $\left(k=0.0052\right.$ day $\left.^{-1}\right)$ compared to unconnected wetlands $(k=0.0030$ day $^{-1}$ ) (Fig. 3a). Connected wetlands also had significantly faster breakdown rates in 2019 compared to $2018\left(k=0.0018\right.$ day $\left.^{-1}\right)$.

Final molar $\mathrm{C}$ : $\mathrm{N}$ ratios were significantly greater in unconnected wetlands compared to connected wetlands $\left(F_{1,40}=7.01, p=0.021\right)$ with no significant difference due to year, mesh size or the interaction. Overall, increased reduction in $\mathrm{C}: \mathrm{N}$ over the experiment in connected versus unconnected wetlands was the due to greater reduction in $\mathrm{C}$ in connected wetlands (Fig. 3b). Final molar C: $\mathrm{P}$ ratios were greater in unconnected wetlands $\left(F_{1,40}=5.83, p=0.031\right)$ and marginally greater in 2018 compared to 2019 $\left(F_{1,40}=3.92, p=0.056\right)$. In 2018 this difference among wetland types were largely driven by W69, while a greater period of flow in 2019 increased P immobilization in both W69 and W04 sequentially along the flow path (Fig. 3c). Final molar N: P ratios were significantly greater in 2018 than $2019\left(F_{1,40}=15.21, p<\right.$ $0.001)$ and were marginally greater in unconnected wetlands $\left(F_{1,40}=3.56, p=0.081\right)$ (Fig. 3d). Temporal patterns of litter nutrient content showed net immobilization of nitrogen $(\mathrm{N})$ across all wetland types and mesh sizes with some difference between years. In 2019, litter in fine mesh of unconnected wetlands showed $\mathrm{N}$ mineralization in the first few months followed by immobilization resulting in differences between wetland types until the final sampling (Fig. 4a). Phosphorus $(P)$ revealed more distinct patterns in both years. In 2018, coarse and fine mesh leaves accrued greater $P$ in connected wetlands compared to unconnected, though this trend was largely driven by W69, the most upstream wetland. In 2019, only coarse mesh litter showed distinct differences with connected wetlands having a greater rate of $P$ immobilization (Fig. 4b).

\section{Macroinvertebrate Community}


Many of the macroinvertebrates present in the wetlands were small enough to gain access to our fine mesh litter, including many Chironomidae and ostracods resulting in fine mesh having an overall greater total abundance than coarse mesh bags $\left(F_{1,117}=26.69, p<0.001\right)$ (Fig. $\left.5 a\right)$. The interaction of sampling date and wetland type was significant $\left(F_{5,117}=F=6.24, p<0.001\right)$. In 2018, the total abundance was marginally greater in unconnected wetlands within one day of filling, similar on day 7 and marginally less by the late colonization point. In 2019 , connected wetlands had greater abundances on all sampling dates. This increased abundance was largely the result of ostracods and non-tanypodinae chironomids. When shredder abundance was compared, the interaction of sampling date and wetland type was only marginally significant $\left(F_{5,117}=113.59, p=0.090\right)$ and no difference was seen between mesh sizes, indicating that our dominant shredders were able to gain access to fine mesh litter bags (Fig. 5b). No significant differences were seen between wetland types on differing sampling dates in 2018. In 2019, wetlands were similar until the late colonization point when connected wetlands had marginally greater shredder abundances (Fig. 5b).

\section{Discussion}

Our study shows that intermittent connectivity between agricultural lands and GIWs increases litter breakdown rates when compared to unconnected wetlands. The effect of connection appears transient as decay rates were greatest in 2019 when wetlands were connected for an extended period while no difference in decay rate was observed in 2018. Our study was in a region that experienced 3 multi-year severe droughts from the late 1990s until 2013 (Supplement A). Since 2014, less extreme seasonal wet and dry cycles have occurred with Palmer Drought Severity Index (PDSI) mostly ranging from -2 to 2 . This study shows that even relatively small differences in water availability (i.e., 2018 and 2019) can cause divergent patterns in nutrient uptake and organic matter processing. The mild interannual variability among our two study years not only changed nutrient processing within the wetlands but also potential carbon storage via leaf litter. Overall, our results highlight how the timing and duration of flow paths across space impact ecosystem structure and function.

When our results are placed within the context of previous litter decomposition studies, we note that our connected wetlands functioned more similarly to flowing waters while our unconnected wetlands functioned similar to discrete wetlands (Fig. 6). Our study also suggests that final nutrient immobilization by litter provided the most comprehensive view of subsidies in our wetlands as litter appeared to absorb substantial nutrient runoff and the wetlands themselves resulted in nutrient uptake from adjacent land that was not consistently seen in our water quality measures. Collectively, these results are consistent with previous studies showing that hydrologic subsidies of nutrients, particularly P, promote litter breakdown through relaxation of nutrient limitation (e.g., Battle and Golladay 2007). Macroinvertebrate abundances were variable within the system, though total and shredder abundances tended to be greater in the most upstream wetland during connection. Likely microbial processes were a larger driver of breakdown within this system despite some increases in invertebrate abundance with connection. Overall, 


\section{Temporal and Spatial Variability in Water Flowpaths Impacted Wetland Function}

Our study further highlights that spatial arrangement and temporal patterns of connectivity strongly regulate ecosystem structure and function. Dissolved phosphorus in the water column varied markedly as a result of spatial arrangement with $P$ being higher in the wetland immediately downstream from agricultural fields and declining precipitously in a downstream trajectory when wetlands were connected. In contrast, unconnected wetlands remained comparatively low in P. Patterns of DOC showed variable levels with no apparent difference between connected and unconnected wetlands in 2018. In 2019, lower DOC levels were observed in connected wetlands with greater intermittent flow (Fig. 2a). This is consistent with DOC originating as leachates from soil organic matter, largely absent in agricultural settings, as well as flushing occurring during hydrologic pulses (Golladay et al. 2000, Raymond et al. 2016).

In addition to increased nutrients, flow pulses in connected wetlands could provide transient increases in dissolved oxygen levels as well as promote physical breakdown. Cuffney and Wallace (1987) and Day (1982) noted greater litter breakdown in flowing swamps compared to non-flowing swamps. They attributed differences in breakdown to both physical processing and greater oxygen levels supporting biological processing. In our study, W69 was the only wetland with a noticeable channel running through it and litter bags were placed just outside of this incised area to better duplicate conditions in other wetlands. Other studies have shown that flow into river-adjacent wetlands can increase breakdown rates, although like our study, these observations are often confounded with increased nutrient levels as well (Cuffney and Wallace 1987; Sampaio et al. 2008; Taylor et al. 2017).

\section{Enhanced Litter Breakdown and Altered Litter Stoichiometry in Intermittently Connected Wetlands}

Our ecosystem function of interest, litter breakdown also exhibited similar differences temporally and spatially. While our leaf litter breakdown rates were slow (e.g., Webster and Benfield 1986), they were comparable to rates found in wetlands with similarly recalcitrant litter species (Fig. 6). The extended connection in 2019 increased mean breakdown rates 2.5x in the most upstream wetland (W69) with increased rates at downstream wetlands by 1.6x (W04) and 1.1x (W68), sequentially. Previous studies examining water quality have shown a significant reduction in SRP from the inflow to outflow of W04 indicating the role of net nutrient uptake by wetlands along this flowpath (Deemy and Rasmussen 2017). Nutrient enrichment has been shown to increase breakdown in many studies (e.g., Gulis and Suberkropp 2003; Kominoski et al. 2015; Taylor et al. 2017) and our study highlights the role of sequential nutrient reduction and litter decomposition along the flowpath. Water quality samples showed increased TDP predominantly in W69 only. High TDP concentrations from runoff and reduced residence during 2019 
may have saturated uptake and increased transport rate and account for greater TDP concentration in the upstream wetland. Wetlands downstream had lower TDP concentration but uptake of $P$ by litter occurred as evident by low C:P and N:P in remaining litter. In addition, W04 is a large wetland and water samples were not taken in the inlet (i.e., Deemy and Rasmussen 2017), but within the wetland at sites of litter breakdown. Relatively rapid breakdown in W04 in addition to W69 (most upstream) is consistent with increased $P$ availability enhancing microbial production.

Increased nutrient availability can increase litter processing by stimulating microbial activity (e.g., Suberkropp and Chauvet 1995, Lee and Bukaveckas 2002). While we did not directly measure microbial activity, a previous study found that ergosterol levels in a subset of our study wetlands was relatively high for a low oxygen system (Battle and Golladay 2001). Previous studies at Ichauway have noted Plimitation in forested wetlands based on analyses of soil and litterfall nutrient content (Watt and Golladay 1999; Craft and Casey 2000). In addition, agricultural wetlands tend to have elevated SRP concentrations in the region and can potentially act as sinks for nutrient runoff (Atkinson et al. 2011; Deemy and Rasmussen 2017). Battle and Golladay (2007) noted that microbial assemblages were stimulated by nutrient containing flood pulses which promoted litter breakdown, consistent with our results. N:P ratios were lowest in the most upstream wetland which had the most immediate agricultural connection with litter $\mathrm{N}: \mathrm{P}$ decreasing at downstream wetlands. Litter $\mathrm{N}: \mathrm{P}$ potentially shifted from strong $\mathrm{P}$ limitation to $\mathrm{N}$ and $\mathrm{P}$ co-limitation in 2019. Also, lower $\mathrm{N}: \mathrm{P}$ values have been shown to favor bacterial assemblages over fungal assemblages, adding diverse microbial processes to litter breakdown depending upon environmental conditions (Güsewell and Gessner 2009).

\section{Macroinvertebrate Response between Connected and Unconnected Wetlands}

While there were no clear patterns in macroinvertebrate abundances in 2018, connected wetlands consistently had a greater total abundance when flow was present in 2019. Connection among these wetlands and upstream wetlands and flowpaths likely facilitated colonization. Fine mesh bags often had the greatest total abundance, largely because of small ostracods and non-tanypodinae that were abundant in the wetlands. This is potentially the result of reducing larger predator invertebrates from accessing ostracods and non-tanypodinae in fine mesh bags. While predator abundances were not notably higher in coarse mesh bags, access to small invertebrates is possible in the coarse mesh size. Shredder abundances, largely amphipods and isopods, were similar in 2018 and at the start of 2019, yet differences were seen at the late colonization point with greater shredder abundances in connected wetlands. No direct association with litter breakdown rates and shredder abundance was noted because of high variability which has been seen in previous studies (Battle and Golladay 2001; Fuell et al. 2013). However, wetlands with a greater abundance of macroinvertebrates tended to have greater breakdown rates. This suggests that while macroinvertebrates played a role in breakdown, microbial processes interacting with nutrient levels and flow are likely a larger driver of litter breakdown within this system.

\section{Conclusions}


Our study, like previous studies (e.g., Battle et al.. 2007) showed that litter processing rates were variable depending upon climate patterns (degree of water availability) and landscape position (proximity to disturbed areas, connectedness). This variability shows the challenge of assessing GIW function at a landscape scale. Two important wetland functions, nutrient uptake and organic matter processing (or carbon sequestration) varied greatly over a relatively small geographic area depending upon water availability and hydrologic connectedness. To understand wetland function at a landscape scale, data from diverse wetlands over a range of climate patterns, topographies, and vegetation composition is essential. In our study, intermittent flow pulses originating in agricultural areas during wet periods increased breakdown along a gradient of wetland connectivity. Pulsed flows provided subsidies that relaxed nutrient limitation. These flow periods also enhanced important wetland functions like the ability to process agricultural runoff before it could contaminate groundwater or surface water.

Climate change predictions within the southeastern US have shown an increased variability in rainfall with larger storm events occurring during winter months. This intensification of storms will likely increase the frequency with which these connections occur (Sun 2013; Golladay et al. 2016). More information is needed on how this will affect year to year carbon storage and nutrient cycling within GIWs that would allow for extrapolation of these importance wetland functions to a landscape or decadal time scale. Modifying wetland distribution across the landscape could result in alterations to the important connections that are present. Understanding how seasonal and decadal climate variability interact with land use to alter wetland function is necessary for better understanding the varying roles wetlands play at a landscape scale.

\section{Declarations}

Funding: Funding for this study was provided by The Jones Center at Ichauway.

Conflicts of interest/Competing interests: The author's declare no conflict of interest.

Availability of data and material: The data is available from the corresponding author on reasonable request.

Code availability: The R code is available from the corresponding author on reasonable request.

Authors' contributions: CS, SG conceptualized and designed the study. CS and BC collected data. CS analyzed data. CS, SG, CA and BC wrote the manuscript. All authors read and approved the final manuscript.

Ethics approval: Not applicable

Consent to participate: Not applicable

Consent for publication: Not applicable 


\section{Acknowledgements}

We are grateful to the following people for assisting in field and laboratory work: Bryan Cloninger, Wesley Giddens, Morgan Burchfiel, Molly McGuigan and Jillian Hochstrasser. We thank Arial Shogren and two anonymous reviewers for their comments. Funding was provided by the Jones Center at Ichauway and the Robert W. Woodruff Foundation

\section{References}

1. Atkinson CL, Golladay SW, First MR (2011) Water Quality and Planktonic Microbial Assemblages of Isolated Wetlands in an Agricultural Landscape. Wetlands 31:885-894. doi:10.1007/s13157-0110203-6

2. Bates D, Maechler M, Bolker B, Walker S (2015) Fitting Linear Mixed-Effects Models using Ime4. J Stat Softw 67:1-48. doi:10.18637/jss.v067.i01

3. Battle JM, Golladay SW (2007) How hydrology, habitat type, and litter quality affect leaf breakdown in wetlands on the gulf coastal plain of Georgia. Wetlands 27:251-260

4. Battle JM, Golladay SW (2001) Hydroperiod influence on breakdown of leaf litter in cypress-gum wetlands. Am Midl Nat 146:128-145

5. Benfield EF (2006) Decomposition of leaf material. In: Hauer FR, Lamberti (eds) Methods in stream ecology. Academic Press, Sand Diego, California, pp 711-720

6. Botello G, Golladay S, Covich A, Blackmore M (2013) Immature mosquitoes in agricultural wetlands of the coastal plain of Georgia, U.S.A.: Effects of landscape and environmental habitat characteristics. Ecological Indicators 34:304-312. doi: 10.1016/j.ecolind.2013.05.018

7. Capps KA, Rancatti R, Tomczyk N et al (2014) Biogeochemical Hotspots in Forested Landscapes: The Role of Vernal Pools in Denitrification and Organic Matter Processing. Ecosystems 17:14551468. doi:10.1007/s10021-014-9807-z

8. Cohen MJ, Creed IF, Alexander L et al (2016) Do geographically isolated wetlands influence landscape functions? Proceedings of the National Academy of Sciences 113:1978-1986. doi: $10.1073 /$ pnas. 1512650113

9. Craft CB, Casey WP (2000) Sediment and nutrient accumulation in floodplain and depressional freshwater wetlands of Georgia. USA Wetlands 20:323-332 i: 10.1672/02775212(2000)020[0323:SANAIF]2.0.CO;2 ) :. do

10. Cuffney TF, Wallace JB (1987) Leaf litter processing in Coastal Plain stream and floodplains of southeastern Goergia, USA. Arch für Hydrobiol 76:1-24

11. Day FP Jr (1982) Litter decomposition rates in the seasonally flooded Great Dismal Swamp. Ecology 63:670-678

12. Deemy JB, Rasmussen TC (2017) Hydrology and water quality of isolated wetlands: Stormflow changes along two episodic flowpaths. Journal of Hydrology: Regional Studies 14:23-36. doi:10.1016/j.ejrh.2017.10.001 
13. Faulkner S (2004) Urbanization impacts on the structure and function of forested wetlands. Urban Ecosystems 7:89-106. doi:10.1023/B:UEC0.0000036269.56249.66

14. Fortino K, Hoak J, Waters MN (2020) Evidence for positive priming of leaf litter decomposition by contact with eutrophic pond sediments. Hydrobiologia 847:137-149. doi:10.1007/s10750-01904077-0

15. Fuell AK, Entrekin SA, Owen GS, Owen SK Valley (2013) Drivers of Leaf Decomposition in Two Wetland Types in the Arkansas River. USA Wetlands 33:1127-1137. doi:10.1007/s13157-013-0468-z

16. Gessner MO, Chauvet E (2002) "A Case for Using Litter Breakdown to Assess Functional Stream Integrity. " Ecological Applications 12(2):498-510

17. Golladay SW, Martin KL, Vose JM et al (2016) Achievable future conditions as a framework for guiding forest conservation and management. For Ecol Manage 360:80-96.

doi:10.1016/j.foreco.2015.10.009

18. Golladay SW, Watt K, Entrekin S, Battle J (2000) Hydrologic and geomorphic controls on suspended particulate organic matter concentration and transport in Ichawaynochaway Creek, Georgia, USA. Archiv fur Hydrobiologie 149:655-678

19. Gulis V, Suberkropp K (2003) Leaf litter decomposition and microbial activity in nturient-enriched and unaltered reaches of a headwater stream. Freshw Biol 48:123-134

20. Güsewell S, Gessner MO (2009) N: P ratios influence litter decomposition and colonization by fungi and bacteria in microcosms. Funct Ecol 23:211-219. doi:10.1111/j.1365-2435.2008.01478.x

21. Kohler SL, Corti D, Slamecka MC, Schneider DW (1999) Prairie floodplain ponds: Mechanisms affecting invertebrate community structure. In: Batzer DP, Rader RB, Wissinger SA (eds) Invertebrates in freshwater wetlands of North America: Ecology and management. John Wiley and Sons, New York, pp 711-730

22. Kominoski JS, Rosemond AD, Benstead JP et al (2015) Low-to-moderate nitrogen and phosphorous concentrations accelerate microbially driven litter breakdown rates. Ecol Appl 25:856-865

23. Lee AA, Bukaveckas PA (2002) Surface water nutrient concentrations and litter decomposition rates in wetlands impacted by agriculture and mining activities. Aquat Bot 74:273-285

24. Lenth R (2020) emmeans: Estimated Marginal Means, aka Least-Squares Means

25. Martin GI, Kirkman LK, Hepinstall-Cymerman J (2012) Mapping Geographically Isolated Wetlands in the Dougherty Plain. Georgia USA Wetlands 32:149-160. doi:10.1007/s13157-011-0263-7

26. McClain ME, Boyer EW, Dent CL et al (2003) Biogeochemical Hot Spots and Hot Moments at the Interface of Terrestrial and Aquatic Ecosystems. Ecosystems 6:301-312. doi:10.1007/s10021-0030161-9

27. Merritt RW, Cummins KW, Berg MB (eds) (2008) America, An Introduction to the Aquatic Insects of North, 4th edn. Kendall Hunt

28. Paramenter RR, Lamarra VA (1991) Nutrient cycling in a freshwater marsh: The decomposition of fish and waterfowl carrion. Limnol Oceanogr 36:976-987 
29. Pechmann JHK, Scott DE, Gibbons W, Semlitsch RD (1989) Influence of wetland hydroperiod on diversity and abundance of metamorphosing juveniles amphibians. Wetland Ecology Management 1:3-11

30. R Core Team (2020) R: A Language and Environment for Statistical Computing

31. Raymond PA et al (2016) Hydrological and biogeochemical controls on watershed dissolved organic matter transport: pulse-shunt concept. Ecology 97(1):5-16. doi:10.1890/14-1684.1

32. Reiss KC (2006) Florida Wetland Condition Index for depressional forested wetlands. Ecol Ind 6:337352. doi:10.1016/j.ecolind.2005.03.013

33. Richardson CJ (1994) Ecological functions and human values in wetlands: A framework for assessing forestry impacts. Wetlands 14(1):1-9

34. Rosemond AD, Swan CM, Kominoski JS, Dye SE (2010) Non-additive effects of litter mixing are suppressed in a nutrient-enriched stream. Oikos 119:326-336. doi:10.1111/j.1600-

0706.2009.17904.x

35. Sampaio A, Rodriguez-Gonzalez P, Varandas S et al (2008) Leaf litter decomposition in western Iberian forested wetlands: lentic versus lotic response. Limnetica 27:93-10

36. Solórzano L, Sharp JH (1980) Determination of total dissolved phosphorus and particulate phosphorus in natural waters1. Limnol Oceanogr 25:754-758. doi:10.4319/lo.1980.25.4.0754

37. Suberkropp K, Chauvet E (1995) Regulation of leaf breakdown by fungi in streams: influences of water chemistry. Ecology 76:1433-1445

38. Sun G (2013) Impacts of climate change andvariability on water resources in the Southeast USA. In: Climate of the Southeast United States. Island Press, Washington, DC, pp 210-236

39. Tank JL, Rosi-Marshall EJ, Griffiths NA, Entrekin SA, Stephen ML (2010) A review of allochthonous organic matter dynamics and metabolism in streams. Journal of the North American Benthological Society 29(1):118-146

40. Taylor JM, Lizotte RE, Testa S, Dillard KR (2017) Habitat and nutrient enrichment affect decomposition of maize and willow oak detritus in Lower Mississippi River Basin bayous. Freshwater Science 36:713-725. doi:10.1086/694452

41. Thorp JH, Covich AP (eds) (2009) Ecology and Classification of North American Freshwater Invertebrates. Academic Press

42. Tiner RW (2003) Estimated extent of geographically isolated wetlands in selected areas of the United States. Wetlands 636. doi: https://doi.org/10.1672/0277-5212(2003)023[0636:EEOGIW]2.0.CO;2

43. Vanni MJ (2002) Nutrient Cycling by Animals in Freshwater Ecosystems. Annu Rev Ecol Syst 33:341-370. doi:10.1146/annurev.ecolsys.33.010802.150519

44. Watt KM, Golladay SW (1999) Organic Matter Dynamics in Seasonally Inundated Forested Wetlands of the Gulf Coastal Plain. Wetlands 19:139-148

45. Webster JR, Benfield EF (1986) Vascular Plant Breakdown in Freshwater Ecosystems. Annu Rev Ecol Syst 17:567-594. doi:10.1146/annurev.es.17.110186.003031 
46. Wickham H (2016) ggplot2: Elegant Graphics for Data Analysis. Springer-Verlag, New York 47. Zedler PH (2003) Vernal Pools and the Concept of "Isolated Wetlands. Wetlands 23:597

\section{Figures}

a.

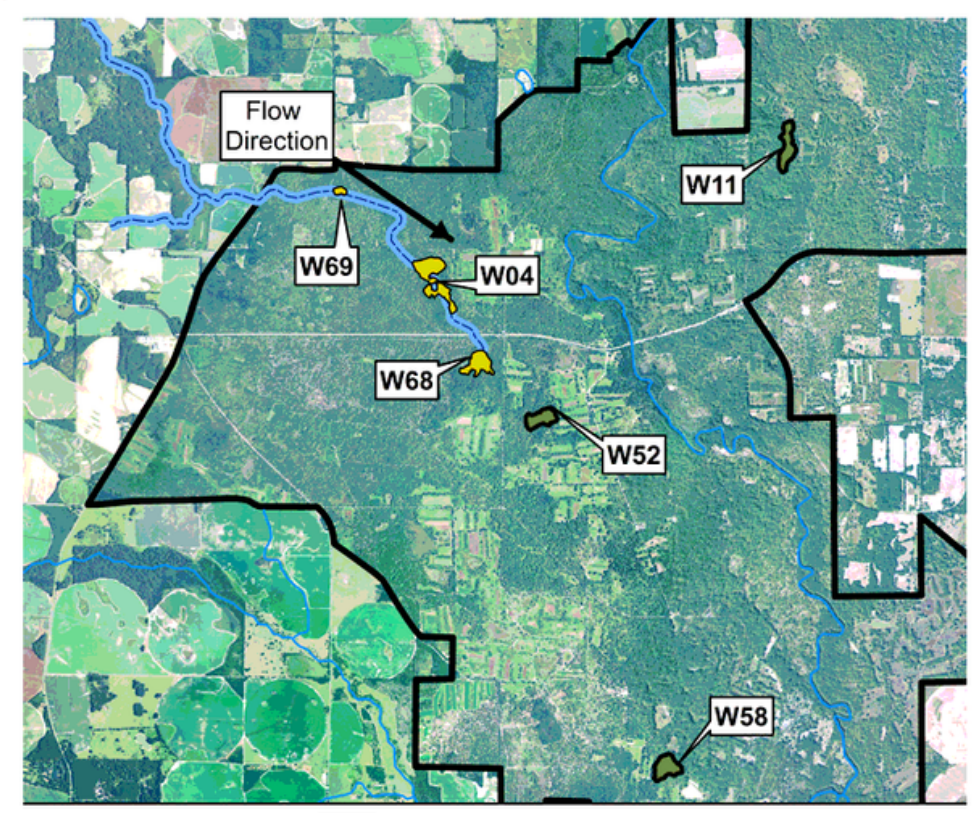

Connected Unconnected - Streams - Study Stream
The Jones Center at Ichauway

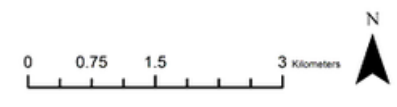

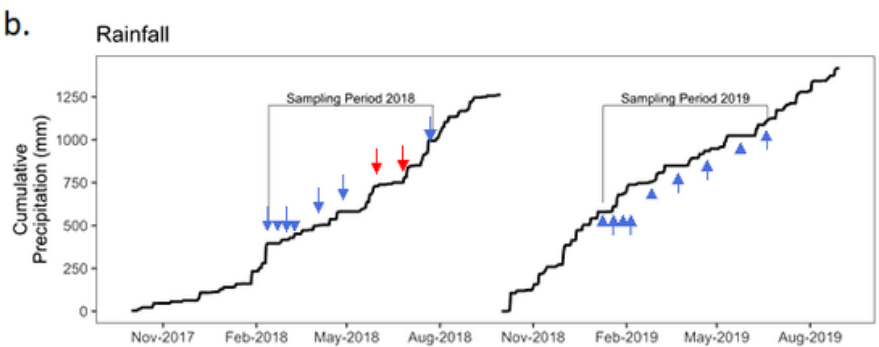

Wetland Inundation
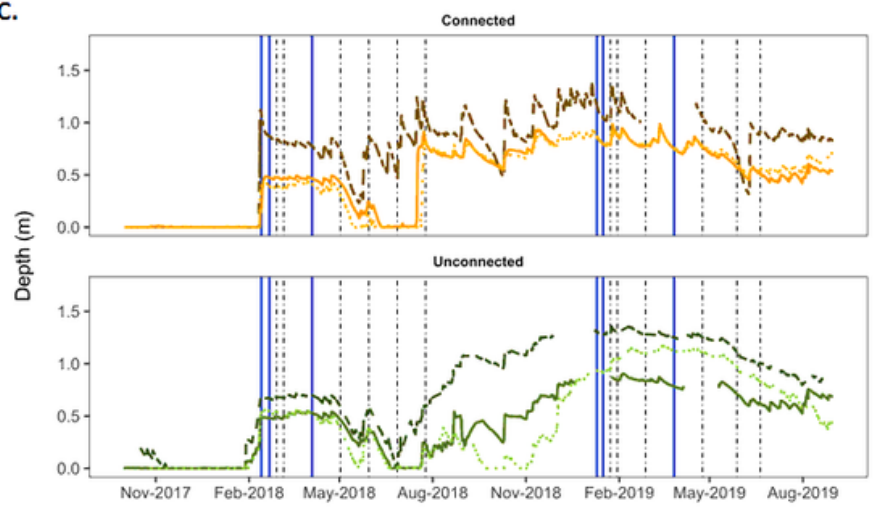

$\begin{aligned} &- \text { W69 } \text { W11 } \\ & \text { Wetland } \text { W04 } \\ & \text { W68 } \text { W52 } \\ & \text { W68 }\end{aligned}$

\section{Figure 1}

a) Map of the Jones Center at Ichauway with wetlands connected along an intermittent flow path shown with blue dotted line and those that are unconnected. b) Graph of daily rainfall totals and c) hourly water levels across wetlands in connected and unconnected wetland types. Solid blue vertical lines indicate litter collection and macroinvertebrate collection while dashed black lines indicate date of litter collection. Blue arrows in $\mathrm{b}$ indicate collection dates where water was present at most litter sites while red indicate dry periods. 
a

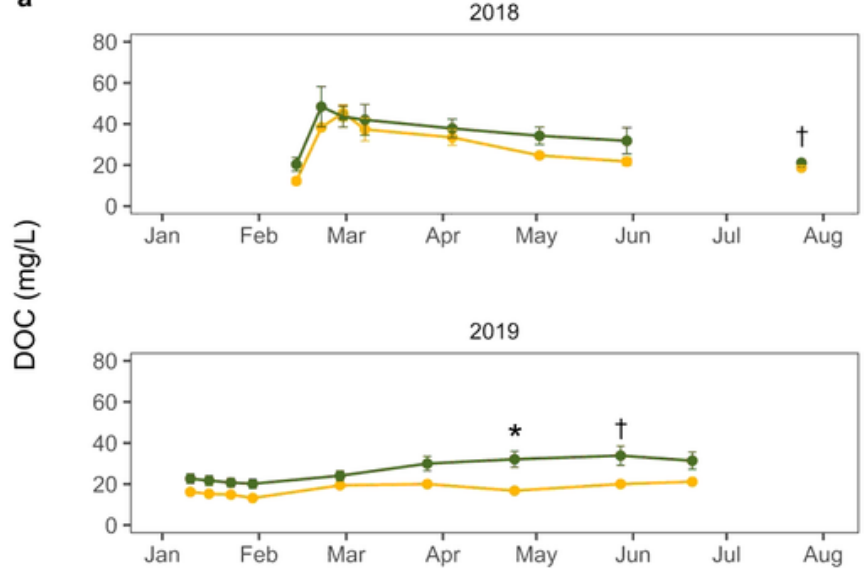

b

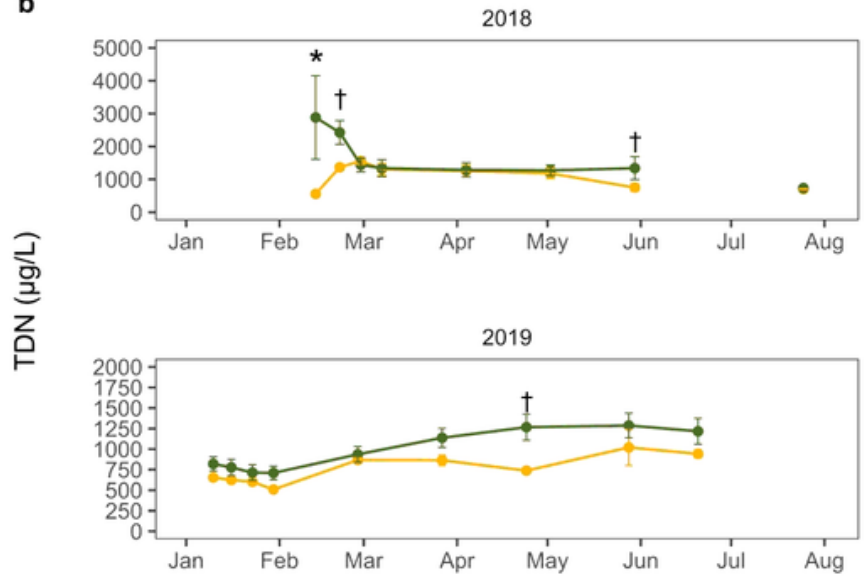

c

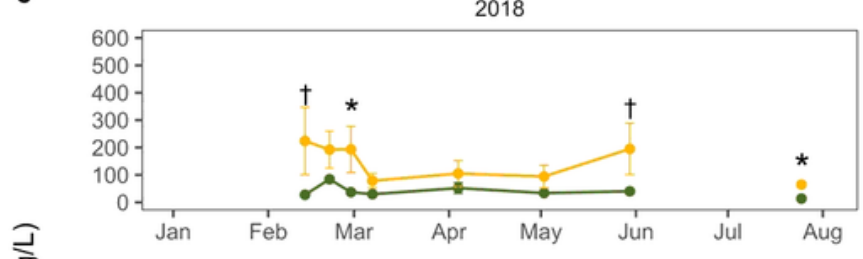

혹

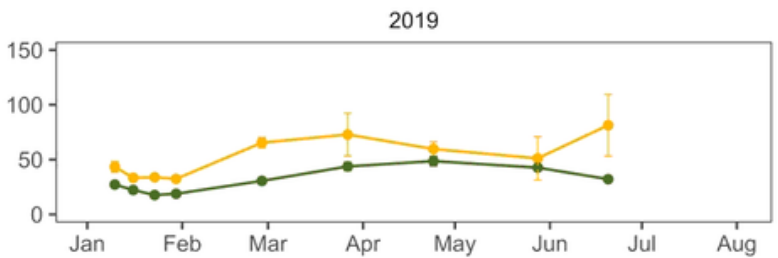

2018

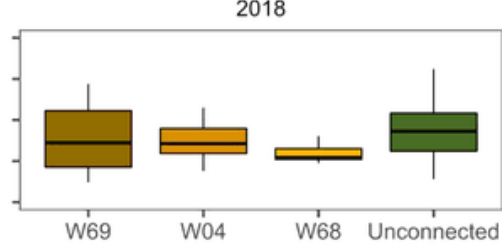

2019

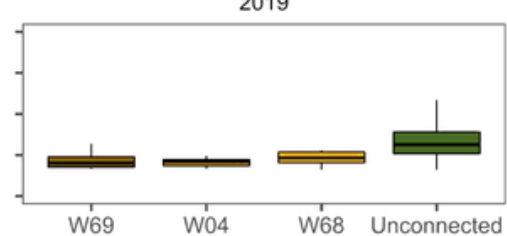

2018

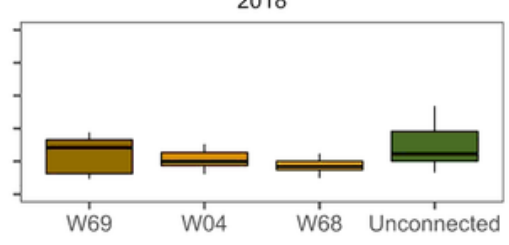

2019

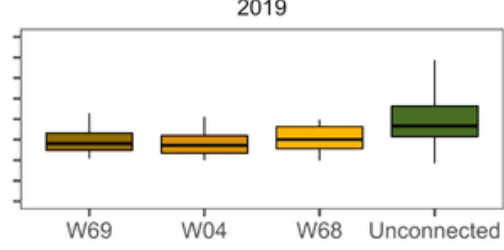

2018
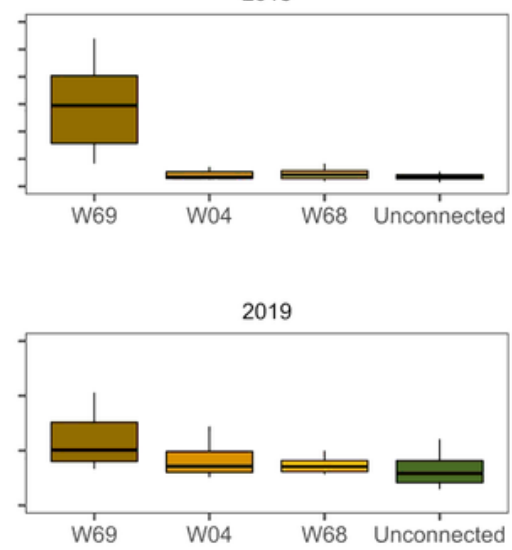

Wetland Type - Connected - Unconnected

\section{Figure 2}

a) Map of the Jones Center at Ichauway with wetlands connected along an intermittent flow path shown with blue dotted line and those that are unconnected. b) Graph of daily rainfall totals and c) hourly water levels across wetlands in connected and unconnected wetland types. Solid blue vertical lines indicate litter collection and macroinvertebrate collection while dashed black lines indicate date of litter collection. 
Blue arrows in $b$ indicate collection dates where water was present at most litter sites while red indicate dry periods.
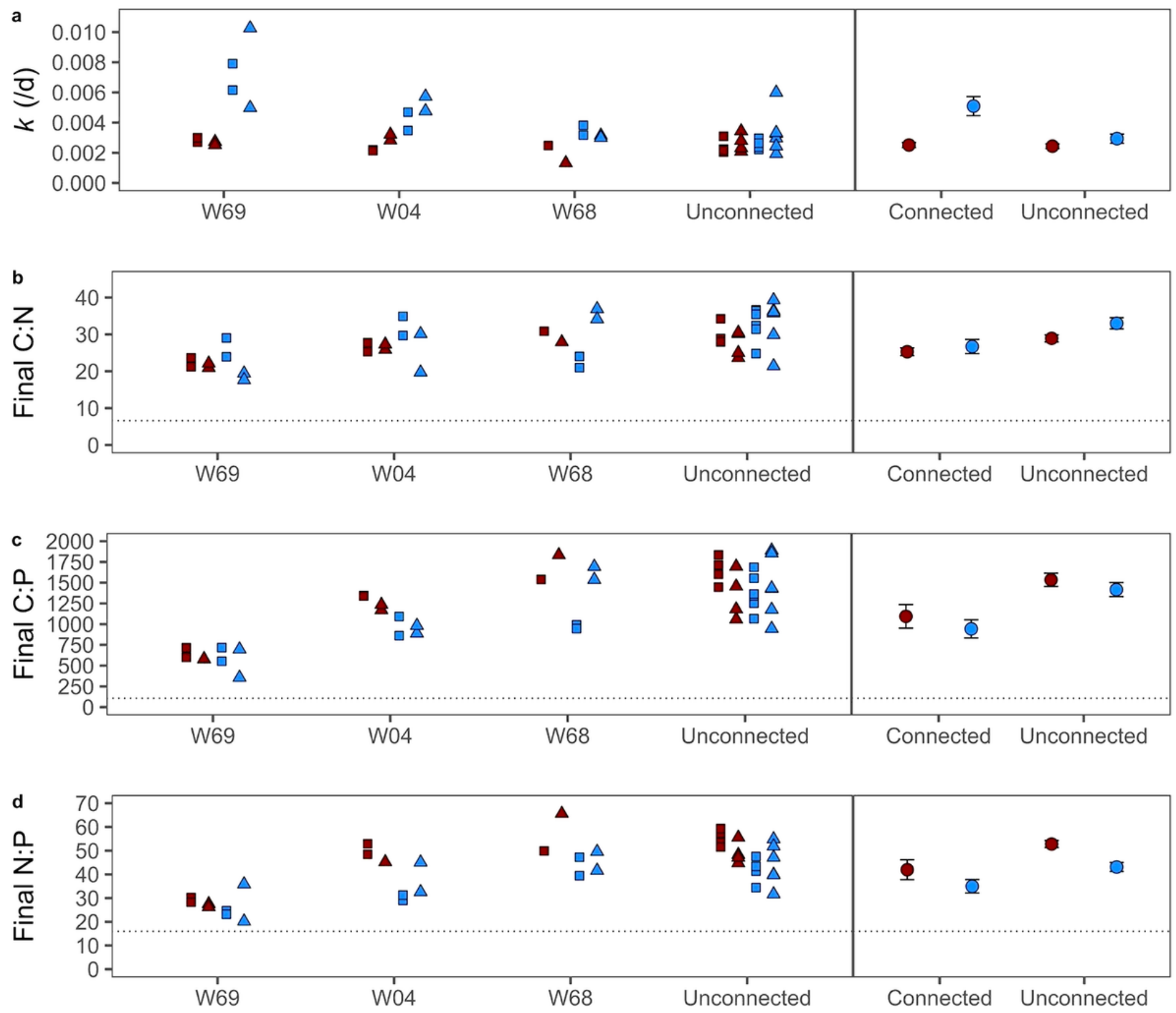

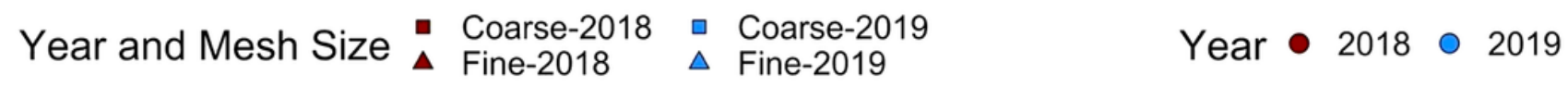

\section{Figure 3}

a) Litter breakdown rate expressed per day, b) final molar C:N, c) final molar C:P and d) final molar N:P. Left panel figures show variability among various connected wetlands to unconnected wetlands in the different mesh sizes. Right panel shows mean $\pm S E$ of each wetland type in each year. The dotted horizontal line indicates Redfield ratio. 

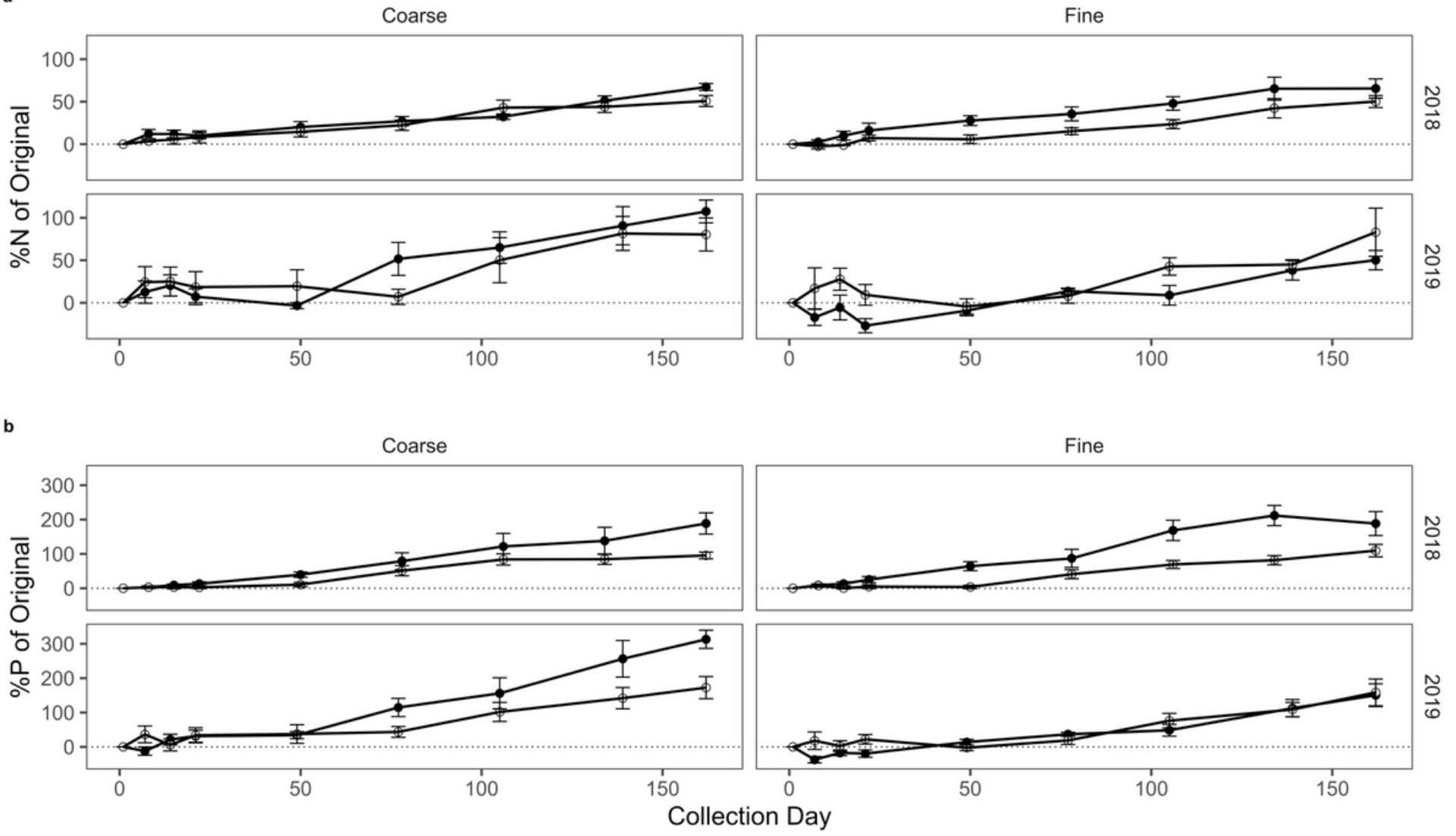

Wetland Type • Connected $\circ$ Unconnected

Figure 4

Mean $\pm S E$ of percent nitrogen (a) and phosphorus (b) of litter over time relative to the starting values between wetland types and mesh sizes across years. Dotted lines indicate original levels. 


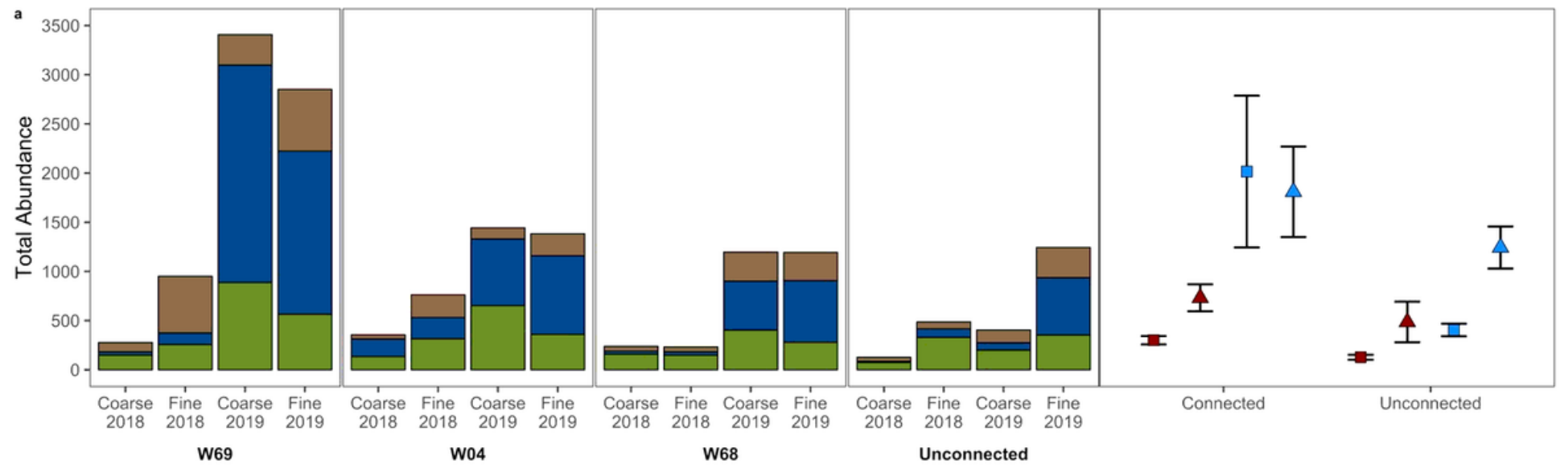

Taxa $\square$ Chironomidae $\square$ Ostracoda $\square$ Other Year and Mesh Size $\boldsymbol{\Delta} \underset{\text { Fine-2018 }}{\text { Coarse-2018 }} \underset{\text { Fine-2019 }}{\text { Coarse-2019 }}$

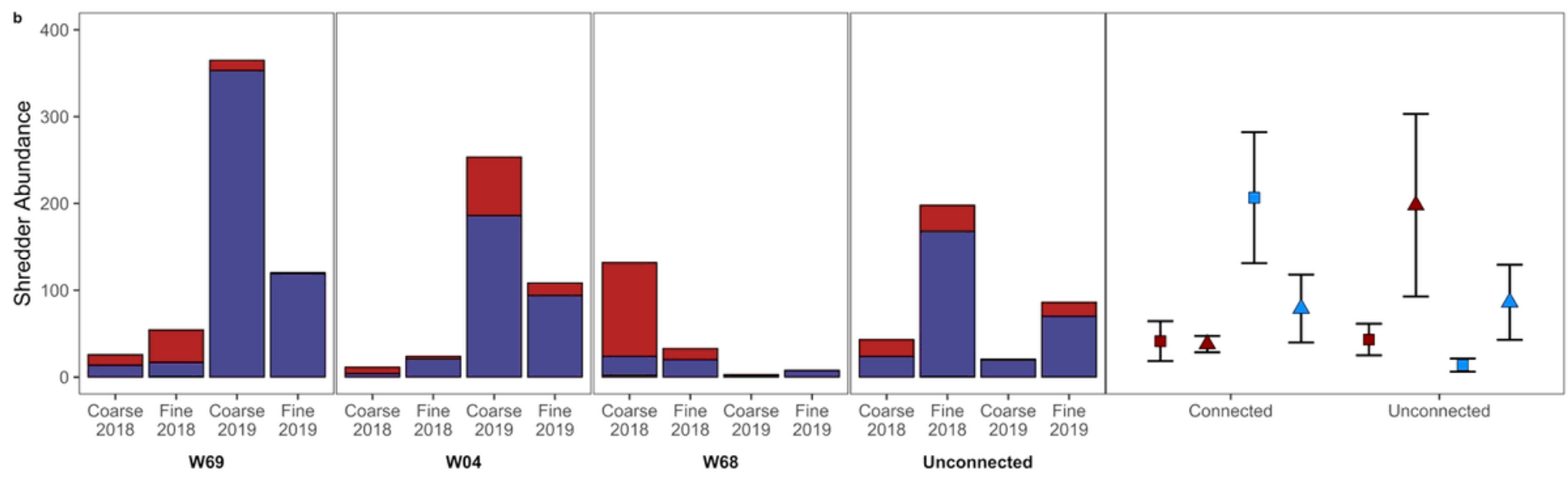

Taxa $\square$ Amphipoda $\square$ Isopoda $\square$ Other

Year and Mesh Size $\underset{\Delta}{\text { Cine-2018 }} \underset{\Delta \text { Fine-2019 }}{\text { Coarse-2018 }}$

Figure 5

Late Colonization total abundance (a) and shredder abundance (b) per bag. In the left panels, mean abundance at each wetland or category are shown for each mesh size, year combination broken down by the dominant taxa. The far right panel shows mean $\pm S E$ abundance per bag between mesh size in each year in connected and unconnected wetlands. 


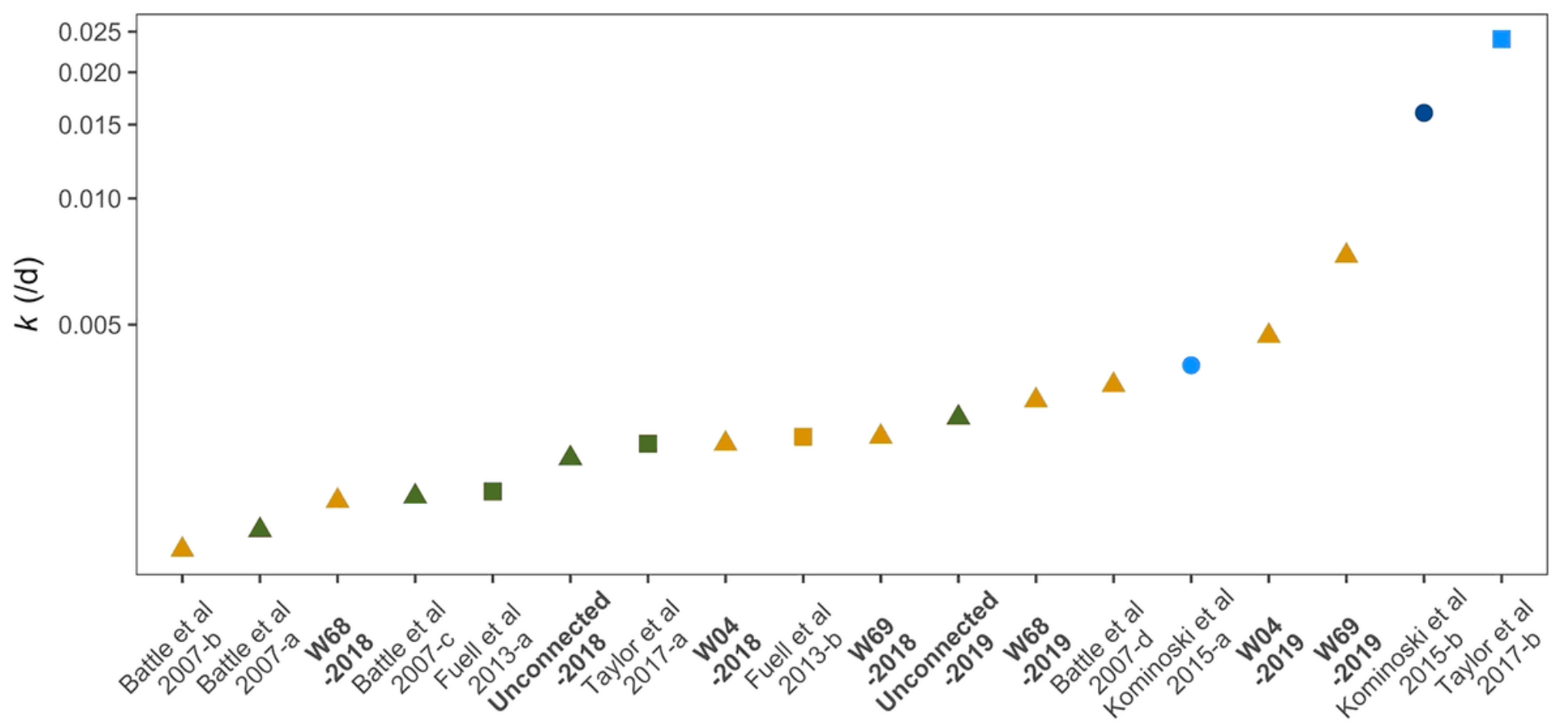

Flow/Nutrient Conditions $\bullet$ Unconnected $\bullet$ Connected $\bullet$ Lentic $\bullet$ Lentic+P

\section{Leaf Species $\bullet$ A. rubrum $\boldsymbol{\Delta}$ N. sylvativa $\mathbf{\square}$ Q.phellos}

\section{Figure 6}

Comparison of breakdown rate per day in ascending order from varying studies with similarly recalcitrant litter species. Studies range from wetlands that are unconnected to those that are connected (i.e., slough or backwaters on rivers) to lentic studies with added phosphorus. Our study wetlands are in bold along the $x$-axis. If breakdown rates were not directly reported in the manuscript, approximation from graphs were used.

\section{Supplementary Files}

This is a list of supplementary files associated with this preprint. Click to download.

- supplementtable1.docx

- Supplementalfigure1.png 